\title{
Cytokine Receptor-Like Factor 2
}

National Cancer Institute

\section{Source}

National Cancer Institute. Cytokine Receptor-Like Factor 2. NCI Thesaurus. Code C97432.

Cytokine receptor-like factor 2 ( $371 \mathrm{aa}, \sim 42 \mathrm{kDa}$ ) is encoded by the human CRLF2 gene. This protein is involved in the mediation of both cytokine binding and signaling. 